\section{Regards sur l'économie allemande}

Bulletin économique du CIRAC

$110 \mid 2013$

Varia

\title{
Libéralisme politique
}

GENSCHER Hans-Dietrich, LINDNER Christian, Brückenschläge. Zwei Generationen, eine Leidenschaft

\section{(2) OpenEdition}

Journals

Édition électronique

URL : http://journals.openedition.org/rea/4602

DOI : $10.4000 /$ rea.4602

ISSN : 1965-0787

Éditeur

CIRAC

Édition imprimée

Date de publication : 15 octobre 2013

Pagination : 39

ISSN : 1156-8992

Référence électronique

"Libéralisme politique », Regards sur l'économie allemande [En ligne], 110 | octobre 2013, mis en ligne le 16 octobre 2013, consulté le 22 septembre 2020. URL : http://journals.openedition.org/rea/4602 ; DOI : https://doi.org/10.4000/rea.4602

Ce document a été généré automatiquement le 22 septembre 2020

(C) CIRAC 


\section{Libéralisme politique}

GENSCHER Hans-Dietrich, LINDNER Christian, Brückenschläge. Zwei

Generationen, eine Leidenschaft

\section{RÉFÉRENCE}

GENSCHER Hans-Dietrich, LINDNER Christian, Brückenschläge. Zwei Generationen, eine Leidenschaft, Hoffmann und Campe Verlag, Hambourg, 2013, 254 p.

1 La défaite historique du parti FDP aux élections au Bundestag du 22 septembre 2013 donne une actualité toute particulière à ce dialogue entre deux générations de libéraux, incarnées d'un côté par Hans-Dietrich Genscher (né en 1927), elder statesman qui joua un rôle déterminant tant dans l'Unité allemande que la construction européenne et, de l'autre, Christian Lindner (1979), l'actuel président du FDP. La longue succession de défis relevés par ce parti qui a marqué de son empreinte la naissance du modèle démocratique et économique allemand (et en partie européen) montre que ce "parti des libertés » - à commencer par celle de penser - dispose d'une base solide sur laquelle se reconstruire et renouveler son rôle "d'aiguille de la balance » dans le jeu des forces politiques. (ib) 